\title{
ABRASIVE WATERJET CUTTING OF INCONEL 718 ALLOY AND DESIRABILITY ANALYSIS
}

\author{
Lenin K. ${ }^{1}$, Thileepan S. ${ }^{2}$, Ravi kumar H. ${ }^{3}$ \\ ${ }^{1}$ Post Graduate Scholar, Department of Mechanical Engineering, Saveetha Engineering College, Chennai, India \\ 2,3 Department of Mechanical Engineering, Saveetha Engineering College, Chennai, India \\ Email: leninkathir@gmail.com
}

\begin{abstract}
Abrasive waterjet cutting (AWJC) is a non-traditional machining process employed to handle stronger materials. Inconel 718 alloy is a material which is difficult to handle by traditional machining process. The present work is focused towards studying the surface roughness and kerf width obtained in AWJC of Inconel 718 alloy. The abrasive waterjet parameters like the water pressure, feed rate and abrasive flow rate are included in experimentation. The quality characteristics are observed for the various combinations of the cutting parameters designed by Taguchi's $L_{9}$ orthogonal array. Desirability analysis is employed for predicting the optimal setting of AWJC parameters and analysis of variance (ANOVA) is performed to identify the contribution of various parameters in affecting the responses. The confirmation experiment is also conducted to validate the proposed approach.
\end{abstract}

Key words: Abrasive waterjet cutting; Inconel 718; Surface roughness; Kerf width; Desirability analysis; ANOVA.

\section{INTRODUCTION}

Waterjet technology is used to cut materials in pure form or in a combined form along with abrasives. Abrasive waterjet cutting (AWJC) has wide industrial applications because of its merits including zero thermal distortion and environmental friendliness. The process limitation includes an unwanted noise and a messy workplace. The process involves focusing of an abrasive waterjet through a small orifice at supersonic speeds to perform the required operation [1]. The process responses depend on the values of cutting parameters and the cost of the abrasives constitute nearly $50 \%$ of the total operating cost [2]. Inconel 718 alloy having typical applications in gas turbines, pumps, rocket motors and space crafts is chosen to be machined using AWJC process. The input parameters like water pressure, feed rate and abrasive flow rate are observed to influence the process responses. Hence selecting an optimal combination of AWJC parameters is important for better responses. Parameter design can be sorted out using methods like the technique for order of preference by similarity to ideal solution (TOPSIS), genetic algorithm (GA), principal component analysis (PCA), grey relational analysis (GRA), response surface methodology (RSM), simulated annealing (SA), fuzzy logic and desirability analysis $[3,4,5,6,7]$.
The RSM is a statistical method which generates a polynomial equation to relate the responses with the process inputs [8]. The technique is observed to lose its vigour away from the experimental domain $[9,10]$. However the experimentations using orthogonal array rather than the central composite design is found to be economical because of a reduced number of experimental trials [11,12]. Taguchi technique is found to be effective in optimization of single response, however Taguchi based desirability analysis which involves calculation of composite desirability index is effective in predicting the optimal operating condition $[13,14,15]$. Generally the methodology of RSM is supplemented by desirability analysis $[16,17]$. The Taguchi based PCA is found to perform well and forecast the optimal parameter setting as well $[18,19]$.

From the literature review, it is understood that desirability analysis involves simple computational procedure for multi response optimization. Further limited work is addressed in the area of parameter design in AWJC of Inconel 718 alloy. Hence an attempt has been made to identify the optimal setting of AWJC parameters for the Inconel 718 alloy. 


\section{EXPERIMENTAL SETUP AND OBSERVATIONS}

The material chosen for machining trials is Inconel 718 alloy widely used in turbines and spacecraft applications. The cutting trials are performed using waterjet Germany cutter (model: S3015, SL-V $50 \mathrm{HP}$ ), inbuilt with a dual intensifier pump to produce a maximum possible pressure of $4000 \mathrm{bar}$. The waterjet is focused via a sapphire nozzle (diameter $0.76 \mathrm{~mm}$ ), controlled by a PLC system. The experimental setup is shown in Fig. 1. The dominant AWJC parameters chosen for experimentation include the water pressure (W), feed rate $(\mathrm{F})$ and abrasive flow rate (A). The range and levels are selected based on literature and pilot trials. Taguchi's $L_{9}$ orthogonal array is used to conduct the trials for various combinations of AWJC parameters during which the jet impact angle is maintained at $90^{\circ}$. Three levels are chosen for various parameters and surface roughness (SR) and kerf width (KW) are measured as the responses. The SR values are measured using contact type roughness tester at all sides of cut and the average values are listed in Table 1. The KW is measured as mean of the top and bottom kerf.

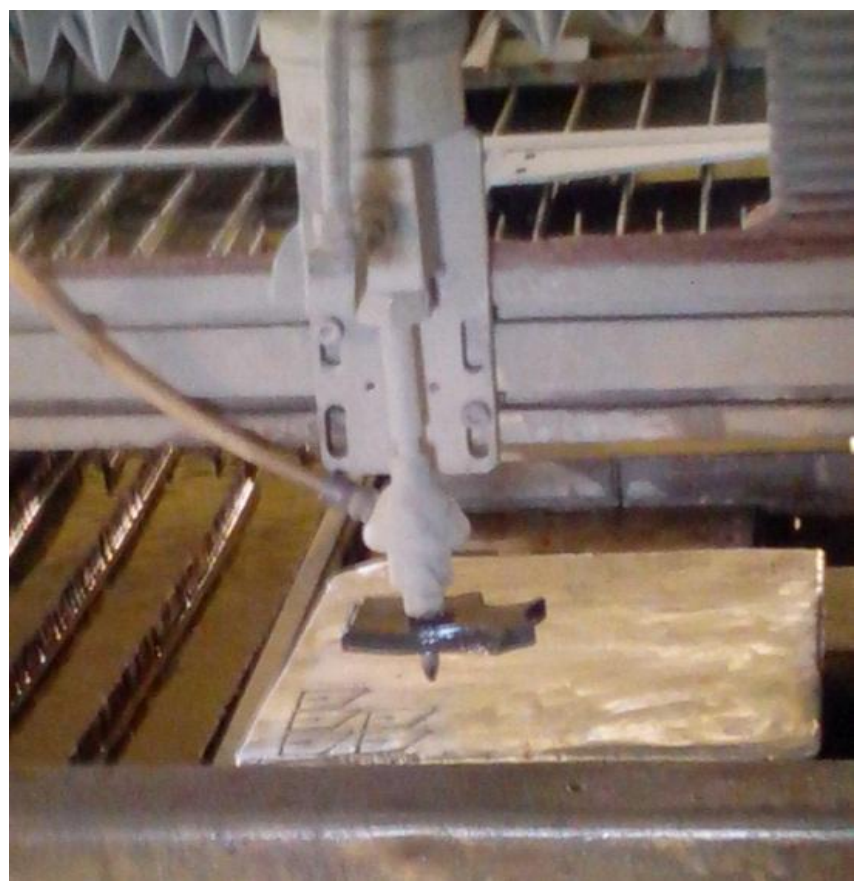

Fig. 1. Experimental setup
Table 1. SR and KW values for various trials

\begin{tabular}{|c|c|c|c|c|c|}
\hline \multirow{2}{*}{ Trial } & \multicolumn{3}{|c|}{ Parameters } & \multicolumn{2}{c|}{ Responses } \\
\cline { 2 - 6 } & $\begin{array}{c}\mathbf{W} \\
(\mathbf{b a r})\end{array}$ & $\begin{array}{c}\mathbf{F} \\
(\mathbf{m m} / \mathbf{m i n})\end{array}$ & $\begin{array}{c}\mathbf{A} \\
(\mathbf{g} / \mathbf{m i n})\end{array}$ & $\begin{array}{c}\text { SR } \\
(\boldsymbol{\mu m})\end{array}$ & $\begin{array}{c}\mathbf{K W} \\
(\mathbf{m m})\end{array}$ \\
\hline 1 & 2000 & 150 & 350 & 5.436 & 0.375 \\
\hline 2 & 2000 & 180 & 450 & 5.523 & 0.358 \\
\hline 3 & 2000 & 210 & 550 & 5.223 & 0.422 \\
\hline 4 & 2700 & 150 & 450 & 5.731 & 0.254 \\
\hline 5 & 2700 & 180 & 550 & 5.046 & 0.231 \\
\hline 6 & 2700 & 210 & 350 & 4.864 & 0.276 \\
\hline 7 & 3300 & 150 & 550 & 4.092 & 0.325 \\
\hline 8 & 3300 & 180 & 350 & 4.962 & 0.333 \\
\hline 9 & 3300 & 210 & 450 & 4.353 & 0.364 \\
\hline
\end{tabular}

\section{SELECTION OF OPTIMAL AWJC PARAMETERS THROUGH DESIRABILITY ANALYSIS}

Selection of optimal AWJC parameters for Inconel 718 alloy is utmost essential to obtain the best cut surface characteristics and avoid further processing. This is bound to reduce the cost in the long run. The desirability function approach is a ranking technique employed to convert the responses into scale free values. The overall desirability index is calculated to predict the optimal condition using the following steps.

Step 1: Find the individual desirability $\left(\mathrm{d}_{\mathrm{ij}}\right)$ values for all the responses using the smaller-the-better-type function (Eq. 1).

$$
d_{i j}=\left(\frac{y_{i j}-L_{i}}{T_{i}-L_{i}}\right)^{s}, \text { if } L_{i} \leq y_{i j} \leq T_{i}
$$

Where $\mathrm{n}$ is the number of variables, $\mathrm{m}$ is the number of trials, $i=1,2 \ldots n$ and $j=1,2 \ldots m, L_{i}$ and $T_{i}$ are the lower and target values of the responses respectively.

Step 2: Compute the overall desirability index (ODI) by taking the average of individual desirability values using Eq. 2. The ODI values lie between 0 and 1 .

$$
\mathrm{ODI}_{\mathrm{j}}=\left\{\Pi_{\mathrm{i}=1}^{\mathrm{n}} \mathrm{d}_{\mathrm{ij}}\right\}^{\frac{1}{\underline{n}}} \text {. }
$$


Step 3: Identify the optimal level of the parameters based on the ODI value. The quality of product is better at higher value of ODI avoiding further cost.

Step 4: Perform the analysis of variance (ANOVA) to identify the contribution of various parameters in affecting the desired responses.

Step 5: Conduct the validation test to approve the followed methodology.

\section{RESULTS AND DISCUSSION}

\section{A. Application of the Methodology of Desirability analysis}

The technique of desirability analysis is applied to the multi-input multi-output process of AWJC. The individual desirability values and ODI are calculated for both the responses and listed in Table 2. The ODI values offer the single representation for both the responses. Cutting trials with higher values of ODI represent a machining condition close to the optimal setting of parameters. The ODI values plotted for various trials are shown in Fig. 2.

Table 2. Individual desirability and ODI values

\begin{tabular}{|c|c|c|c|}
\hline \multirow{2}{*}{ Trial } & \multicolumn{2}{|l|}{ Individual Desirability } & \multirow{2}{*}{ ODI } \\
\cline { 2 - 3 } & SR & KW & \\
\hline 1 & 0.1800 & 0.2461 & 0.2105 \\
\hline 2 & 0.1269 & 0.3351 & 0.2062 \\
\hline 3 & 0.3099 & 0.0000 & 0.0000 \\
\hline 4 & 0.0000 & 0.8796 & 0.0000 \\
\hline 5 & 0.4179 & 1.0000 & 0.6465 \\
\hline 6 & 0.5290 & 0.7644 & 0.6359 \\
\hline 7 & 1.0000 & 0.5079 & 0.7126 \\
\hline 8 & 0.4692 & 0.4660 & 0.4676 \\
\hline 9 & 0.8408 & 0.3037 & 0.5053 \\
\hline
\end{tabular}

\section{B. Optimal Cutting Condition and ANOVA.}

The main effect of the parameters on the ODI is calculated for each level and listed in Table 3 . The best level of each parameter is identified as one with the maximum value of ODI. The optimal parameter level is predicted $\mathrm{W}_{3} \mathrm{~F}_{2} \mathrm{~A}_{3}$. The ANOVA table can be used to study the parameter contribution on responses. The results of ANOVA on ODI are shown in Table 4. The contribution chart is shown in Fig. 3. It gives an account of the share of each parameter in affecting the responses.

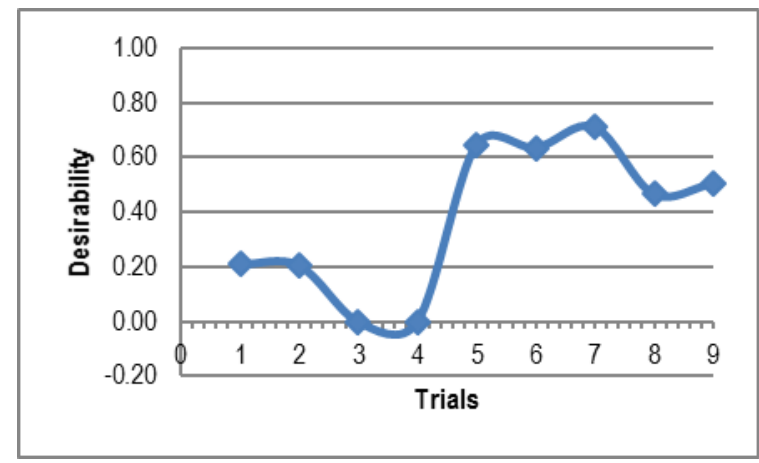

Fig. 2 Plot of ODI values for various cutting trials

Table 3. Parameter effects on CDI

\begin{tabular}{|c|c|c|c|}
\hline Parameters & Level 1 & Level 2 & Max-Min \\
\hline W & 0.1389 & 0.4275 & 0.5618 \\
\hline F & 0.3077 & 0.4401 & 0.3804 \\
\hline A & 0.4380 & 0.2372 & 0.4530 \\
\hline
\end{tabular}

Table 4. ANOVA results

\begin{tabular}{|c|c|c|c|c|c|}
\hline $\begin{array}{c}\text { Source } \\
\text { of } \\
\text { variance }\end{array}$ & $\begin{array}{c}\text { Sum of } \\
\text { squares }\end{array}$ & $\begin{array}{c}\text { Degrees } \\
\text { of } \\
\text { freedom }\end{array}$ & $\begin{array}{c}\text { Mean } \\
\text { sum of } \\
\text { square }\end{array}$ & $\begin{array}{c}\text { F- } \\
\text { ratio }\end{array}$ & $\begin{array}{c}\% \\
\text { Contribution }\end{array}$ \\
\hline W & 0.2802 & 2 & 0.1401 & 1.2488 & 45.33 \\
\hline F & 0.0872 & 2 & 0.0436 & 0.1176 & 14.10 \\
\hline A & 0.2244 & 2 & 0.1122 & 0.3884 & 36.30 \\
\hline Error & 0.0264 & 2 & 0.0132 & & 4.27 \\
\hline Total & 0.6181 & 8 & & & 100 \\
\hline
\end{tabular}

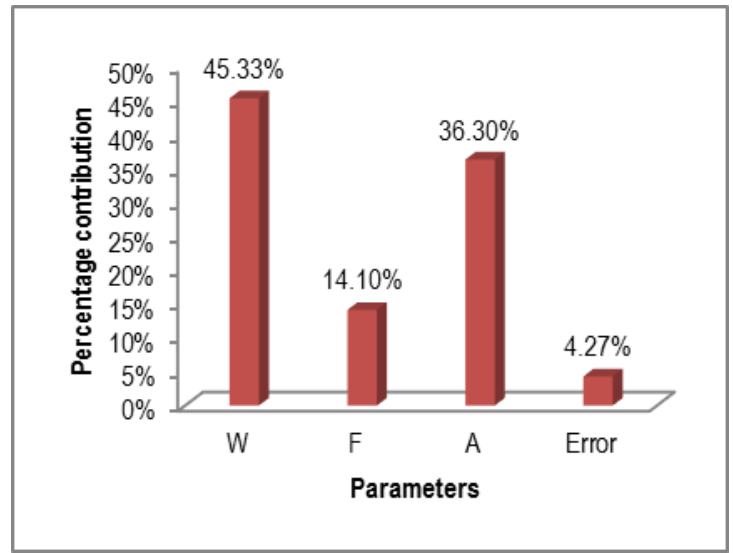

Fig. 3 Factor contribution chart

\section{Validation Experiment}

After obtaining the optimal level of AWJC parameters using the approach of desirability analysis, the confirmation test is conducted to verify the improvement in the performance characteristics. The 
results of the confirmation experiment conducted with the desirable setting are compared with those obtained with initial setting of parameters (Table 5). A significant change in the response values is observed with the optimal design parameters.

Table 5. Validation test results

\begin{tabular}{|c|c|c|c|c|c|c|}
\hline \multirow{2}{*}{$\begin{array}{c}\text { Initial parameter } \\
\text { setting }\end{array}$} & \multicolumn{2}{|c|}{$\begin{array}{c}\text { Optimal setting } \\
\text { using } \\
\text { desirability } \\
\text { analysis }\end{array}$} & \multicolumn{2}{|c|}{ Improvement } \\
\cline { 2 - 7 } $\begin{array}{c}\text { Respo } \\
\text { nses }\end{array}$ & $\begin{array}{c}\text { Calcul } \\
\text { ated } \\
\text { S/N } \\
\text { ratio }\end{array}$ & $\begin{array}{c}\text { Respo } \\
\text { nse } \\
\text { Value }\end{array}$ & $\begin{array}{c}\text { Predic } \\
\text { ted } \\
\text { S/N } \\
\text { ratio }\end{array}$ & $\begin{array}{c}\text { Respo } \\
\text { nse } \\
\text { Value }\end{array}$ & $\begin{array}{c}\text { S/N } \\
\text { rati } \\
\text { o }\end{array}$ & $\begin{array}{c}\text { Respo } \\
\text { nse } \\
\text { Value }\end{array}$ \\
\hline $\begin{array}{c}\mathrm{SR} \\
\text { (um) }\end{array}$ & -12.609 & 4.104 & $\begin{array}{c}- \\
12.231\end{array}$ & 3.814 & $\begin{array}{c}0.37 \\
75\end{array}$ & 0.2900 \\
\hline $\begin{array}{c}\mathrm{KW} \\
\text { (mm) }\end{array}$ & 9.678 & 0.328 & 10.017 & 0.265 & 8.33 & 0.0630 \\
\hline $\begin{array}{c}\text { Parame } \\
\text { ter } \\
\text { settings }\end{array}$ & \multicolumn{2}{|c|}{$\mathrm{W}_{3} \mathrm{~F}_{1} \mathrm{~A}_{3}$} & \multicolumn{2}{|c|}{$\mathrm{W}_{3} \mathrm{~F}_{2} \mathrm{~A}_{3}$} & & \\
\hline
\end{tabular}

\section{CONCLUSION}

This paper has revealed the implementation of desirability analysis to forecast the near optimal AWJC parameters for Inconel 718 alloy. The following conclusions can be drawn.

-The simple computational efforts of desirability analysis is employed to predict the optimal AWJC parameters for Inconel 718 alloy as water pressure: 3300 bar, feed rate: $180 \mathrm{~mm} / \mathrm{min}$ and abrasive flow rate: 550 $\mathrm{g} / \mathrm{min}$.

-The ANOVA result has shown that water pressure is an important parameter influencing the responses with a contribution of $45.33 \%$.

-The confirmation test has validated the application of desirability analysis in selecting the best design parameters.

\section{REFERENCES}

[1] Santhanakumar. M., Adalarasan. R., Rajmohan. M., 2015, Experimental Modelling and Analysis in Abrasive Waterjet Cutting of Ceramic Tiles Using Grey-Based Response Surface Methodology, Arabian Journal for Science and Engineering, 40 (11), pp. 3299-3311.
[2] Kulekci. M.K., 2002, Processes and apparatus developments in industrial waterjet applications, International Journal of Machine Tools and Manufacture, 42, pp. 1297-1306.

[3] Karthikeyan. R., Adalarasan. R., Pai. B.C., 2002, Optimization of Machining Characteristics for Al/SiCp Composites using ANN/GA, Journal of Material Science and technology, 18 (1), pp. 47-50.

[4]Adalarasan. R., Santhanakumar. M., Shanmugasundaram. A., 2014, Optimization of Friction Welding Parameters for AA6061-T6/AA2024-T6 Joints Using Taguchi-Simulated Annealing (TSA) Algorithm, Applied Mechanics and Materials, 592-594, pp. 595-599.

[5]Adalarasan. R., Santhanakumar, M., 2014, Study on Friction Welding of Aluminium based Composites using Desirability Analysis, International Journal on Design \& Manufacturing Technologies, 8(1), pp.1-4.

[6]Adalarasan. R., Shanmuga Sundaram, A., 2015, Parameter design and analysis in continuous drive friction welding of Al6061/SiCp composites, Journal of Mechanical Science and Technology, 29 (2), pp. 769-776.

[7] Santhanakumar. M., Adalarasan. R., 2014, Study of Compression Molding of GFRP using Grey Relational Analysis, International Journal on Design \& Manufacturing Technologies, 8 (1), pp. 36-39.

[8]Adalarasan. R., Santhanakumar. M., Thileepan. S., 2015, Investigation on strength of solid state $\mathrm{Al} 6061 / 30 \% \mathrm{Al}_{2} \mathrm{O}_{3}$ bonds for automotive applications using response surface methodology (RSM), International Journal of Automotive Composites, 1 (4), pp. 364-374.

[9]Adalarasan. R., Santhanakumar. M., 2015, Application of Taguchi based Response Surface Method (TRSM) for Optimization of Multi Responses in Drilling $\mathrm{Al} / \mathrm{SiC} / \mathrm{Al}_{2} \mathrm{O}_{3}$ Hybrid Composite, Journal of the Institution of Engineers (India): Series C, 96 (1), pp. 65-71.

[10] Adalarasan. R., Santhanakumar. M., Rajmohan. M., 2015, Application of Grey Taguchi-based response surface methodology (GT-RSM) for optimizing the plasma arc cutting parameters of 304L stainless steel, International Journal of Advanced Manufacturing Technology, 78 (1), pp. 1161-1170.

[11] Santhanakumar. M., Adalarasan. R., 2014, Application of Grey Taguchi based Response Surface Methodology (GT$\mathrm{RSM}$ ) in Injection Moulding of Polypropylene/E-glass Composite, International Journal of Manufacturing, Materials, and Mechanical Engineering, 5 (1), pp. 35-48.

[12] Adalarasan. R., Santhanakumar. M., Rajmohan. M., 2015, Optimization of laser cutting parameters for Al6061/SiCp/Al2O3 composite using grey based response surface methodology (GRSM), Measurement, 73, pp. 596606.

[13] Adalarasan. R., Santhanakumar. M., 2015, Parameter Design in Fusion Welding of AA 6061 Aluminium Alloy Using Desirability Grey Relational Analysis (DGRA) Method, Journal of the Institution of Engineers (India): Series C, 96(1), pp. 57-63. 
[14] Adalarasan. R., Santhanakumar. M., Rajmohan. M., 2014, Application of desirability analysis for optimizing the micro wire electrical discharge machining ( $\mu$ WEDM) parameters, Applied Mechanics and Materials, 592-594, pp. 77-81.

[15] Atul. S.C., Adalarasan. R., Santhanakumar. M., 2015, Study on Slurry Paste Boronizing of 410 Martensitic Stainless Steel Using Taguchi Based Desirability Analysis (TDA), International Journal of Manufacturing, Materials, and Mechanical Engineering, 5 (3), pp. 64-77.

[16] Adalarasan. R., Santhanakumar. M., 2015, Response surface methodology and desirability analysis for optimizing $\mu$-WEDM parameters for Al6351/20\% $\mathrm{Al}_{2} \mathrm{O}_{3}$ composite, International Journal of ChemTech Research, 7 (6), pp. 2625-2631.
[17] Santhanakumar. M., Adalarasan. R., Rajmohan. M., 2015, Parameter design in plasma arc cutting of galvanised iron sheet using desirability function based response surface methodology (DRSM), International Journal of Manufacturing Research, 10 (3), pp. 199-214.

[18] Adalarasan. R., Shanmuga Sundaram. A., 2015, Parameter design in friction welding of $\mathrm{Al} / \mathrm{SiC} / \mathrm{Al} 2 \mathrm{O} 3$ composite using grey theory based principal component analysis (GT-PCA), Journal of the Brazilian Society of Mechanical Sciences Engineering, 37 (5), pp. 1515-1528.

[19] Adalarasan. R., Santhanakumar. M., Shanmugasundaram, A., 2014, Optimization of weld characteristics of friction welded AA 6061-AA 6351 joints using grey-principal component analysis (G-PCA), Journal of Mechanical Science and Technology, 28 (1), pp. 301-30. 